\title{
The Influence of Knowledge Towards Prevention of Malaria in Relapse Patients in Sawang Subdistrict, Aceh Selatan Regency
}

\author{
Sri Rosita ${ }^{1}$ \\ Master of Public Health Science \\ University of Sumatera Utara \\ Medan, Indonesia \\ srirosita134@yahoo.co.id
}

\author{
Ida Yustina ${ }^{2}$ \\ Department of Health Policy and Administration \\ University of Sumatera Utara \\ Medan, Indonesia \\ idayust@yahoo.com \\ Irnawati Marsaulina ${ }^{3}$ \\ Department of Environmental Health \\ University of Sumatera Utara \\ Medan, Indonesia \\ irnawatimarsa@yahoo.com
}

\begin{abstract}
Malaria is one of a contagious infectious disease that has been a public health problem. Sawang Subdistrict which is located in Aceh Selatan district is an endemic malaria area. The objective of this research is to analyse the influence of knowledge toward prevention of malaria in relapse patients at Sawang, Aceh Selatan. Mixed methods of concurrent embedded model (quantitative and qualitative) were applied in this research. The samples taken were all malaria relapse patients which counted to 56 people in Health Center Sawang in Aceh Selatan on January-December 2016. Data collection was done by interview using questionnaire which then to be analysed using multiple logistic regression at $\alpha=0.05$. This study concluded that there was an influence of knowing the forestalling of malaria in relapse patients at study area. It was proposed to Head of Aceh Selatan District Administration collaborate do immigration survey, periodic entomological survey and also recommended to management in Health Center Sawang should provide counselling about forestalling malaria intensively and specifically by involving the patients' families. The patients were advised to use mosquito nets and non-revealing clothes.
\end{abstract}

Keywords-Knowledge; prevention; malaria relapse

\section{INTRODUCTION}

The success of Indonesia's development is determined by the availability of qualified human resources. To obtain these resources, the development of health is one of the decisive elements because the society must be free from various diseases, especially infectious diseases. Infectious diseases are still a prominent public health problem, including malaria. This infectious disease can affect all age groups, especially in high-risk groups that are in infants, children under five and pregnant women that have an impact on degrading the quality and productivity of human resources even causing death, so that immediate precautions are needed to solve the malaria problem World Health Organization (WHO) recorded that half the world's population (3.2 billion people from 95 countries) has at risk of malaria. In 2015, it was found 214 million malaria cases and 438,000 cases were caused death, while the highest endemic malaria found in African countries [1].

In 2011, the prevalence of malaria is $6.0 \%$ with five provinces has the highest percentage of incidence and prevalence; Papua (28.6\%), East Nusa Tenggara (23.3\%), West Papua (19.4\%), Central Sulawesi (12.5\%) and Maluku (10.7\%) (Riskesdas, 2013). In Indonesia, Malaria cases were managed by control the Decree of the Minister of Health of the Republic of Indonesia Number.293 / MENKES / SK / IV / 2009 [2].

The malaria problem is difficult to overcome, since the incidence of illness may be repeated (35-40 times over a period of 3-4 years) (3). The impact is the declining quality of community human resources so policymakers must approach systematically, efficiently and effectively to deal with malaria [4]. Forero et al. (2014) and Babamale et al. (2015) found a significant effect of knowledge about the prevention of malaria. Lisanuddin et al. (2016) reveals that the low level of General knowledge of statistically significant for the prevention of malaria.

Malaria is preventable and curable, so precaution is one of the important actions to tackle malaria. Act health RI Number 36, 2009 of Health States that infectious disease prevention effort is the shared responsibility of the Government, local authorities and communities. Malaria prevention indicators according to KEMENKES RI (2014) namely sleeping wear mosquito nets, wearing anti mosquito, install the wire gauze and wearing clothes that covered.

The control of malaria in Indonesia stated in a decision of the Minister of health of the Republic of Indonesia number 293/MENKES/SK/IV/2009 dated April 28, 2009 about the Malaria Elimination which aims to bring about a society of healthy living, which is independent of malaria transmission in 
stages until 2030. Activities performed in the exercise of malaria control programs such as early diagnosis through examination, laboratory confirmation of blood preparations as well as Rapid Diagnostic Test (RDT) malaria and treat all cases of malaria (positive sufferers malaria drug) with the effective and safe the set defined by the Ministry of health, namely ACT (Artemisinin Combination Therapy), screening for malaria on pregnant women, gift of mosquito nets, and outreach.

Sawang sub district is endemic malaria in South Aceh Regency, with a percentage increase in malaria cases was positive from the year 2014, 2015 and 2016, from $4.6 \%$ to 93.3\%. Sawang sub district there are many streams along the rice fields, bushes and wild quarry opened by society without any oversight from the local government. The highest incidence of malaria in South Aceh Regency is in the SubDistrict of Sawang. Annual Malaria Insidence (AMI) of $15.38 \%$ in 2015 increase to be $43.08 \%$ in 2016 . Figures for the incidence of malaria cases per thousand of the population as measured by Annual Parasite Incidence (API) $<1 / 1000$ population risky. API at Sawang Subdistrict category by village Middle Case incident (MCI) (Panton Village 11.92\%), village of Blang Geulinggang $(5.96 \%)$, village of Kuta Baro (2.99\%), village Sikilat (2.907 \%), Desa Mutiara (2.786 Sawang Village I (1.104\%), Sawang Village II $(3.584 \%)$, village Meuligo (1.164\%) (South Aceh Health Office Profile, 2016).

Based on the results of the interview against 10 people sufferers relapsed Sawang Sub district, obtained in the result that 8 people $(80 \%)$ do not use mosquito nets with mosquito nets ever reason they use as long as it has been damaged, do not use mosquito nets because it has use the anti mosquito, received no Division netting from health workers, 6 persons $(60 \%)$ do not use the anti mosquito with reason: the presence of a perceived negative effects such as respiratory disorders due to the smoke generated from anti-inflammatory drugs mosquitoes, 7 persons $(70 \%)$ do not use a wire gauze on the grounds do not understand about the use of wire gauze, not knowing the function of wire gauze placed on ventilation of the home and the financial to buy a wire gauze, 8 people ( $80 \%$ ) do not wear clothes that covered (clothes long sleeve) when out of the House at night with a hot reason because it is the area near the sea.

\section{MATERIALS AND METHOD}

Study area is located at Sawang sub-district, Aceh, Indonesia. Sawang is one of malaria endemic area which has a high percentage of malaria relapse cases from $47.61-80.64 \%$ [5]. Based on the Ministry of Health of Republik Indonesia, there are several indicators of malaria preventions such as sleeping using mosquito nets, using mosquito repellent, instal wire netting, and wear covered clothes [6].

The quantitative and qualitative methods were applied on the research. The quantitative method is the primary method used by distributing questionnaires to relapse patient in
Sawang, Aceh Selatan. Meanwhile the qualitative method is the second method on the research by conducting in-depth interviews with relapse patient and relapsing patient's family.

\section{A. Sample}

The sample is the entire population of malaria sufferers relaps listed, medical treatment and get treatment with antimalarial drugs in Clinics Sawang in January-December 2016 amounted to 56 people. The population sample was 56 relapse patients, and all of them were used as the samples (total sampling).

\section{B. Study Instruments}

The type of data used in this research is primer data. The collection of primer data was conducted by directly interviewing of compassing to structural questioner which has been prepared. The secunder data was used to support the result by interview. It required by report in Health Center Sawang. Health office of Aceh Selatan, previous study and health journal with related to the research.

\section{Statistical Analysis}

The Statistical Package for Social Science (SPSS) program was used for data analysis. The knowledge and attitude information of the respondents were calculated and tabulated for descriptive statistics. The influence of knowledge was examined using multiple logistic regressions. Initially, the data were analyzed using simple logistic regression to select the significant variables with p-values less than 0.25 . Then, the significant variables were included in a multiple logistic regression. Qualitative data retrieved from data reduction, data display and conclusion drawing/verification. After analyzing the data and then continued with the validity of qualitative data, namely by means of triangulation. Triangulation in this study is to compare the information from informants that one with another informant so that information obtained his righteousness, next, done the member check is to check the validity of the data.

\section{RESULT}

TABLE I.

DISTRIBUTION OF RESPONDENTS BASED ON THE CHARACTERISTICS OF INDIVIDUAL IN PUSKESMAS SAWANG

\begin{tabular}{|c|l|c|c|}
\hline No & Individual Characteristics & Amount & Percent \\
\hline & Age & & \\
\hline 1 & $17-40$ Years (early adulthood) & 44 & 78.6 \\
\hline 2 & 41-59 Years (adulthood) & 12 & 21.4 \\
\hline & \multicolumn{1}{|c|}{ Total } & $\mathbf{5 6}$ & $\mathbf{1 0 0 . 0}$ \\
\hline & Gender & & \\
\hline 1 & Male & 53 & 94.6 \\
\hline 2 & Female Total & 3 & 5.4 \\
\hline & & $\mathbf{5 6}$ & $\mathbf{1 0 0 . 0}$ \\
\hline & Education & & \\
\hline 1 & Not Study / Not Elementary & 14 & 25.0 \\
\hline 2 & Elementary (SD) & 20 & 35.7 \\
\hline 3 & Junior High School (SMP) & 9 & 16.1 \\
\hline 4 & Senior High School (SMA) & 7 & 12.5 \\
\hline 5 & DI/DIII/Bachelor & 6 & 10.7 \\
\hline
\end{tabular}




\begin{tabular}{|c|c|c|c|}
\hline & Total & 56 & 100.0 \\
\hline & Pekerjaan & & \\
\hline 1 & Gold miners & 23 & 41.1 \\
\hline 2 & Farmers & 14 & 25.0 \\
\hline 3 & Private & 11 & 19.6 \\
\hline 4 & Housewives & 2 & 3.6 \\
\hline 5 & PNS/TNI/POLRI & 6 & 10.7 \\
\hline & Total & 56 & 100.0 \\
\hline
\end{tabular}

The results showed that most of the respondents aged 1740 years are 44 people $(78.6 \%)$ and 53 people $(94.6 \%)$ are males. A total of 20 people $(35.7 \%)$ had elementary education and $23(41.1 \%)$ working as gold miners.

TABLE II

DISTRIBUTION OF RESPONDENTS BASED ON KNOWLEDGE OF MALARIA SUFFERERS RELAPS SAWANG SUBDISTRICT IN SOUTH ACEH REGENCY

\begin{tabular}{|c|c|c|c|c|c|c|c|}
\hline \multirow[b]{2}{*}{ No } & \multirow[b]{2}{*}{ Knowledge } & \multicolumn{2}{|c|}{ No } & \multicolumn{2}{|c|}{ Yes } & \multicolumn{2}{|c|}{ Total } \\
\hline & & $\mathbf{n}$ & $\%$ & $\mathbf{n}$ & $\%$ & $\mathbf{n}$ & $\%$ \\
\hline 1 & $\begin{array}{lr}\text { Mode } & \text { of } \\
\text { transmission } & \text { of } \\
\text { malaria through } \\
\text { direct contact with } \\
\text { malaria patients }\end{array}$ & 32 & 57.1 & 24 & 42.9 & 56 & 100.0 \\
\hline 2 & $\begin{array}{l}\text { The cause of malaria } \\
\text { is Anopheles } \\
\text { mosquito }\end{array}$ & 30 & 53.6 & 26 & 46.4 & 56 & 100.0 \\
\hline 3 & $\begin{array}{l}\text { Efforts to prevent } \\
\text { malaria mosquito } \\
\text { bites are using } \\
\text { mosquito nets during } \\
\text { sleep }\end{array}$ & 29 & 51.8 & 27 & 48.2 & 56 & 100.0 \\
\hline 4 & $\begin{array}{l}\text { Active malaria } \\
\text { mosquito bites in the } \\
\text { morning }\end{array}$ & 36 & 64.3 & 20 & 35.7 & 56 & 100.0 \\
\hline 5 & $\begin{array}{l}\text { Types of mosquito } \\
\text { larvae fish are } \\
\text { goldfish }\end{array}$ & 39 & 69.6 & 17 & 30.4 & 56 & 100.0 \\
\hline 6 & $\begin{array}{l}\text { The habit of being } \\
\text { out of the house until } \\
\text { late at night will } \\
\text { make it easier to bite } \\
\text { malaria mosquitoes }\end{array}$ & 41 & 73.2 & 15 & 26.8 & 56 & 100.0 \\
\hline 7 & $\begin{array}{l}\text { Malaria can be cured } \\
\text { by self-medication }\end{array}$ & 39 & 69.6 & 17 & 30.4 & 56 & 100.0 \\
\hline 8 & $\begin{array}{l}\text { Clinical symptoms of } \\
\text { malaria disease is a } \\
\text { fever reaching } 400^{\circ} \mathrm{C}\end{array}$ & 40 & 71.4 & 16 & 28.6 & 56 & 100.0 \\
\hline 9 & $\begin{array}{l}\text { Malaria can cause } \\
\text { death if treated } \\
\text { promptly }\end{array}$ & 40 & 71.4 & 16 & 28.6 & 56 & 100.0 \\
\hline 10 & $\begin{array}{l}\text { Malaria mosquitoes } \\
\text { can breed in places } \\
\text { where there are } \\
\text { puddles }\end{array}$ & 44 & 78.6 & 12 & 21.4 & 56 & 100.0 \\
\hline
\end{tabular}

TABLE III

DISTRIBUTION OF RESPONDENTS THAT HAS KNOWLEDGE IN MALARIA IN RELAPS PATIENTS

\begin{tabular}{|l|l|l|l|}
\hline \multirow{4}{*}{ Knowledge } & Category & Total & Percent \\
\cline { 2 - 4 } & Bad & 35 & 62.5 \\
\cline { 2 - 4 } & Good & 21 & 37.5 \\
\cline { 2 - 4 } & Total & 56 & 100.0 \\
\hline
\end{tabular}

TABLE IV

DISTRIBUTION OF RESPONDENTS THAT KNOWS PREVENTION OF MALARIA IN RELAPS PATIENTS

\begin{tabular}{|c|c|c|c|}
\hline \multirow{3}{*}{$\begin{array}{c}\text { Prevention of } \\
\text { Malaria }\end{array}$} & Category & Total & Percent \\
\cline { 2 - 4 } & Bad & 38 & 67.9 \\
\cline { 2 - 4 } & Good & 18 & 32.1 \\
\hline
\end{tabular}

TABLE V

RELATIONSHIP OF KNOWING AND PREVENTION OF MALARIA

\begin{tabular}{|c|c|c|c|c|c|c|c|}
\hline \multirow[b]{3}{*}{ Knowledge } & \multicolumn{4}{|c|}{ Prevention of Malaria } & \multirow{2}{*}{\multicolumn{2}{|c|}{ Total }} & \multirow{3}{*}{$p$-value } \\
\hline & \multicolumn{2}{|c|}{ Bad } & \multicolumn{2}{|c|}{ Good } & & & \\
\hline & $\mathbf{n}$ & $\%$ & $\mathbf{n}$ & $\%$ & $\mathbf{n}$ & $\%$ & \\
\hline $\mathrm{Bad}$ & 29 & 82.9 & 6 & 17.1 & 35 & 100 & \\
\hline Good & 9 & 42.9 & 12 & 57.1 & 21 & 100 & 0,005 \\
\hline
\end{tabular}

TABLE VI.

INFLUENCE OF KNOWLEDGE TOWARD PREVENTION OF MALARIA IN RELAPS PATIENTS IN SAWANG, ACEH SELATAN USING LOGISTIC REGRESSION

\begin{tabular}{|l|c|c|}
\hline Variable & $\operatorname{Exp}(\mathbf{B})$ & P Value \\
\hline Knowledge & 4,818 & 0,023 \\
\hline
\end{tabular}

The results showed as many as 32 people $(57.1 \%)$ of respondents did not know that the way of transmission of malaria through direct contact with sufferers of malaria (negative question), as many as 30 people $(53.6 \%)$ do not know that cause malaria is a mosquito, Anopheles, as many as 29 people $(51.8 \%)$ were not aware of an effort to prevent mosquito bites by using anti-malarial bed nets, as many as 36 people $(64.3 \%)$ did not know that the malaria mosquitoes are actively biting in the morning (a question negative) and as many as 39 people (69.6\%) did not know that this type of mosquito larva Eater fish is goldfish (negative question).

Respondents who did not know the habit of being outdoors until late at night will make it easier for the mosquito bitten i.e. $73.2 \%, 69.6 \%$ of respondents did not know malaria can be cured by self-medication, $71.4 \%$ of respondents did not know that clinical symptoms of malaria are fever reaches $40^{\circ} \mathrm{C}$, as many as 40 people $(71.4 \%)$ did not know that malaria can cause death when treated and as many as 44 people $(78.6 \%)$ did not know that malaria could be mosquito breed at the place there is a puddle.

Prevention against malaria is not done by the community. The results showed that as much as 42responden $(75,0 \%)$ responded that not using mosquito nets while sleeping the night, as many as 41 respondents $(73.2 \%)$ replied that it does not use anti mosquitoes while sleeping, as many as 32responden $(57.1 \%$ ) answered that do not use a wire gauze, as many as 38 respondents $(67.9 \%)$ did not use a closed clothing (long sleeved) when out of the House, as many as 36 respondents $(64.3 \%)$ responded that there were clearing the bushes around the House, as many as 49 respondents $(87.5 \%)$ answer that does not follow the rules of the medication from a doctor, as many as 28 respondents (reaction flask 50.0\%) answered that when ill with malaria relapse brought treatment 
to health centers and 28 other people don't seek treatment clinic.

As many as 42 respondents $(75,0 \%)$ of unusual wear anti mosquito spray night, as many as 30 respondents $(53.6 \%)$ responded that participate when there is mutual environmental cleanup, a total of 31 respondents $(55.4 \%)$ responded that did not drink drug malaria until exhausted though the symptoms were gone, as many as $37(66.1 \%)$ of the respondents answered that never follow the guidance about the prevention of malaria in the village, as many as 28 (50.0\%) of the respondents answered that before bed use anti mosquitoes, as many as 39 respondents $(69.6 \%)$ responded that after recovering from malaria not to avoid the pain from mosquito bites, as many as 36 respondents $(64.3 \%)$ answered that there was a dirty cloth are suspended and as many as 34 respondents $(60.7 \%)$ replied that the get out of the House if the day had started the night. Overall prevention of malaria categorized poorly 38 respondents $(67,9 \%)$, whereas with the category either only 18responden (32.1\%).

Table I shows the distribution of respondents that has the knowledge about malaria. The result revealed that $62.5 \%$ respondent has bad knowledge of malaria. Multivariate results with multiple logistic regression statistics test showed that the knowledge of malaria has a significant influence in malaria prevention. This means that the more the patient knows about malaria, the better the prevention can be done. Having known about malaria will affect the prevention of malaria disease that will occur, it supported the theory of Bloom that mentions knowledge is to know what is done and how to do it [8].

Forero et al (2014) and Babamale et al (2015) found a significant effect of knowledge on malaria prevention. On other previous study, Loran's (2013) and Lisanuddin et al (2016) revealed that low public knowledge was statistically significant for malaria prevention [9], [10], [11] and [12]. Efforts to increase community knowledge about malaria disease that has been done by South Aceh District Health Office through officers of eradication and control of malaria disease are by conducting a counselling, however the targeted counselling shall not only be conducted specifically on endemic areas or people susceptible to malaria relapse disease. The methods used in counselling is less well understood by the community because the workers used many words or terms that are difficult to understand by the community. The method mostly used is an ordinary lecture, which respondent found to be boring and unable to pay attention throughout counselling session.

Knowledge largely determine a person behaves, for example in the precautionary measures (health prevention behavior) against malaria, i.e. any act committed by an individual in order to prevent the occurrence of malaria among others, sleep use mosquito nets, the use of the anti mosquito mosquito gauze, installation and taking medication regularly as directed as well as cleaning the House and environs of the rest area/breeding mosquito Anopheles.

Efforts increase public knowledge about malaria has done ole South Aceh Regency health services officers Manager through the eradication of malaria and countermeasures is to implement the extension. However the given community outreach not chosen specifically in endemic region or community that is susceptible to malaria which relaps. In addition, the methods used in extension are also less understandable by the public since labor extension officers use many words or terms that are difficult to understand by the general public. The methods used most often is the usual lecture method and based on the results of the interview respondents said was bored so don't listen to the extension.

The result from interview conducted with Head of Health Office and Malaria Program Coordinator, South Aceh District Health Office said that the counselling program has been applied in the study area with irregular time. On other hand, the integrated method was done by lecturing with topic of malaria and also another topic which has correlation with the main topic such dengue counselling course.

The results obtained from interview with relapse patients found that the reasons why that they did not do prevention such as using mosquito nets was because they were not accustomed to be using bed nets during sleep due to the nets being too small, uncomfortable, damaged, and some of them could not get it during mosquito net distribution by Ministry of Health. Respondents did not use anti-mosquito repellent for various reasons such as the presence of perceived negative effects such as respiratory distress due to smoke produced from anti-mosquito coils and unable to sleep because of the smoke which lead to coughing.

Respondents did not use wire netting on windows and sills because they do not know the function of using wire netting installed in home ventilation. They are also unable to buy wire netting due to financial matters, and in some case, the were lack of knowledge on how to install the wire netting prorperly. The majority of respondents were male. The reason that respondents did not wear closed clothing (long-sleeved clothes) when going out and come back late was due to warm weather making them feels hot wearing long-sleeved clothing. The warm weather was due to the fact that its location was closed by the beach.

\section{DISCUSSION}

The problem of malaria is becoming increasingly difficult to overcome and is expected to be an obstacle to the success of health development because the incidence of illness can be repeated many times. A malaria sufferer may be re-attacked 35 to 40 times over a 3-4 year period [3]. The emergence of relapse or re-attacks in malaria patients are related to the following circumstances: ineffective immune responses from patients, imperfect treatment, reinfection or exposure to repeated mosquito bites are closely related to malaria prevention. The most common cause of re-occurrence, especially in endemic areas, is the presence of reinfection or reinfection that occurs immediately after the patient completes his treatment. Reinfection may occur 14 days after treatment. This is possible if the patient's environment supports the development of malaria vectors so that the patient is always exposed to infective mosquito bites [13]. 
Malaria recurrence is related to poor malaria prevention carried out by the community in Kecamatan Sawang Kabupaten Aceh Selatan in accordance with the indicators set by the Ministry of Health in malaria-endemic areas that is frequently using mosquito nets, mosquito repellent, installing wire netting on the door and windows, and wear covered clothes when going out at night.

The impact caused by the recurrence of malaria was sadly felt when the productive age group is affected, considering that they play important role in society. Short-term losses are easy to reckon with the loss of a productive day from someone suffering from malaria. If a worker is exposed to malaria, at least he/she will lose a working day of 3 to 5 days. If the value of earning per day is represented as the amount of loss in the form of money, then a person who usually earns Rp25.000 per day may loss the opportunity to earn from $\mathrm{Rp} 75,000$ to Rp125,000 when suffering from malaria. Not to mention that the cost of treatment and the number of re-attacks that may occur will increase the economic loss of the patient [14].

According to Gani, the short-term losses caused by malaria can reach 11 - 49\% of the Locally-Generated Revenue (PAD) in some districts/cities [15]. While In the long-term, it turns out to be less significant, however it will still cause disruption of maternal and child health, intelligence, workforce productivity, and harming tourism activities [16].

The best way to prevent relapse is to prevent early infection, especially in malaria-endemic areas. This can be done by providing prophylactic treatment for those who will visit the malaria area. Further prevention of relapse attacks that need to be done is to prevent the occurrence of reinfection by avoiding mosquito bites [3]

In Indonesia, Malaria control is regulated in the Decree of the Minister of Health of the Republic of Indonesia No. 299 / MENKES / SK / IV / 2009 dated 28 April 2009 on the. Italicize Roman symbols for quantities and variables, but not Greek symbols. Use a long dash rather than a hyphen for a minus sign. Punctuate equations with commas or periods when they are part of a sentence, as in Elimination of Malaria aimed at realizing a healthy living community free from malarial transmission gradually until 2030. The malaria control programs implement early diagnosis through blood veterinary examination with laboratory confirmation and Malaria Rapid Diagnostic Test (RDT) and treating all malaria sufferers (positive cases) with effective and safe malaria drugs established by the Ministry of Health, ACT (Artemisinin Combination Therapy), malaria screening for pregnant women, giving insecticide bed nets, house spraying and counselling [2] in the Regulation of the Governor of Aceh Number 40 The year 2010 and the Elimination of Malaria in the District of Aceh Selatan is stated in the Regulation of Aceh Selatan Regent Number 21 the year 2013.

\section{CONCLUSION AND RECOMMENDATION}

Based on the background of writing, objectives and research hypothesis, this research concluded that the knowledge of malaria play as a significant factor in the prevention of malaria in relapse patients in Sawang, Aceh Selatan. It is suggested that the Management of Health Center Sawang should provide counselling about forestalling malaria intensively and specifically by involving the patients' families and patients are also advised to use mosquito nets and wear non-revealing clothes.

\section{ACKNOWLEDGMENT}

We are grateful to the head of the health facility for their assistance in this study. We are also thankful to all of the participants and people who were involved in this study. No conflict of interest.

\section{REFERENCES}

[1] WHO, World malaria report. Geneva: World Health Organization; 2015.

[2] Ministry of Health RI. Basic Health Research, Research and Development Agency of the Ministry of Health of the Republic of Indonesia. Jakarta. 2013.

[3] Barnas, Gp, Relapse Malaria, Health Link Medical College of Winconsin, 2003. (Online), (http://digilib.litbang.depkes.go.id, accessed January 15, 2017.

[4] Aljunid, S.M, Economic Burden of Tropical Disease: Where the Gaps in Universal Health Coverage. Public Health International Conference. 2016.

[5] Aceh Selatan District Health Office. Profile of Aceh Selatan District Health Office. Tapaktuan. 2016

[6] Ministry of Health RI. Malaria Management Guidelines, Blandary Disease Control. Jakarta. 2014.

[7] Sugiyono. Qualitative Quantitative Research Methods and R \& D. Bandung: Alfabeta. 2013.

[8] Notoatmojo, S. 2012. Health Promotion and Health Behavior. Jakarta. Rineka Cipta.

[9] Forero et al. Knowledge, Attitudes and Practice of Malaria in Colombia.2014. On access July 2, 2017.

[10] Babamale et al. Community Knowledge on Transmission of Malaria and ITS Management Practice in Oorepe Local Government. South Western Region. Nigeria. 2015. On access July 1, 2017.

[11] Fransiska, Loran, et al. Community Behavior in Prevention and Treatment of Malaria in Larat Tanimbar Utara Maluku District South east West. 2013. http://repository.unhas.ac.id/handle/123456789/6114 accessed May 18, 2017

[12] Lisanuddin, Climate Change Knowledge Relations and Community Attitudes towards Malaria Incidence in Darul Imarah District of Aceh Besar District. 2016.

[13] Omonuwa, S. Malaria Recurrence Caused by Plasmodium Falciparum, Journal of the American Board of Family Medicine, Vol. 15 No. 2 p159160. 2002.

[14] Sahli, Z. Drug Resistance, New Malignancy for Malaraia Lampung Post, Monday, 2003.

[15] Gani, A, Presentation at the Gebrak Malaria Summit, Pentaloka Gebrak Malaria Pulau Sumatera in Padang, Padang, December 16-18, 2002.

[16] Achmadi, U.F. Regional-Based Disease Management, Printed 1, Jakarta, Kompas Media Nusantara, p 228-248. 2005. 